\title{
Examining the Crises in the Food Sector of Nigerian Agriculture
}

\section{Richard Ilorah}

\section{School of Economics and Management, University of the North}

\begin{abstract}
Food output in Nigeria has deteriorated since the 1970 s, whereas the population continues to grow. Consequently, the country experiences a fall in per capita food production. Grouping the country's food producers under four categories, this paper argues that production has remained a predominantly peasant affair, characterized by subsistency, inefficiency and low productivity. For a way forward out of the food crises, we introduce a theoretical model of the impact of policy mechanisms on agricultural output. We also look at the target group of the policy mechanisms. The paper concludes that to tackle the food crises, the country needs a radical approach to the problem, with emphasis on a total departure from its hitherto subsistence farming to a modern commercial farming.
\end{abstract}

JEL Q18

\section{INTRODUCTION}

Categories of staple food in Nigeria range from root tubers (yam, cocoyam, potato and cassava) to grains (maize, millet, soyabeans, cowpeas, sorghum, wheat and rice). The above list is not exhaustive, though, as there are other staples such as beans, plantains, etc. The tubers as well as rice are produced mainly in the southern thick forest region of the country characterized by heavy rainfall, a long wet season and high humidity. The grains are produced in the northern savannah region that experiences low rainfall, a short wet season and low humidity. Accurate measure of subsistence output (export and domestic commodities) in the country is very difficult, particularly in the case of domestic food commodities. In some cases where data does exist, it is recognized to be very unreliable. Among the reasons for lack of reliable data on food output is the fact that the marketing of food is not as officially organized as is the marketing of cash crops (primary export commodities). Data on food output is therefore based mainly on a national agriculture sample census that gives aggregate estimates based on rural household inquiries and on population 
data which is also unreliable. Interpretations of food crops output levels in Nigeria should therefore be done with great caution.

Early studies on Nigeria suggested that the annual growth rate of food output during the decades before the 1970 s was generally higher than the rate of population growth. For example, during the period 1950-1957, food output grew at an estimated average annual rate of 6.7 per cent, whereas the annual growth rate of population was estimated at 2.5 per cent (Olayide et al., 1982: 87). The annual growth rates of food output during the periods 1960-1967 and 1960/61-1970/71 were estimated at 4 per cent and 3.1 per cent, respectively. The drop during the later period was presumably the result of the Nigerian civil war during the period 1967-1969/70 (Sano, 1983). The major imported food products were not close substitutes for domestically produced food products. In 1957, for example, among the major food imports were sugar, salt, wheaten flour and milk powder, all of which accounted for about 82 per cent of total food imports (Teal 1983, Olayide et al., 1982: 87). By the mid-1960s, the situation still remained more or less the same. Imported food items (excluding sugar) constituted just about 3.1 per cent of the value added of domestic food production (Lewis, 1967: 11). The imported food products during those years were considered as luxuries. Their imports therefore did not reflect food shortages in the country. In other words, the imported food products were not necessarily the staples consumed by most Nigerians.

Real stagnation in the output of food started in the 1970s. Output declined at an estimated average annual rate of 4.3 per cent during the first half of the decade. Estimates by the World Bank (1999: 25) revealed that during the period 19651997, agricultural value added (net output) grew at an average annual rate of 1.5 per cent, and the total population at a rate of 2.9 per cent. Even though in Nigeria agricultural production includes not only food but also non-edible agricultural products (like cotton and rubber), both categories are produced by the same farmers using the same farming techniques and facilities. All indications are that Nigerians, on the whole, were no better off in terms of per capita availability of food than they were in terms of per capita availability of non-edible agricultural products (Todaro, 1994, Chapter 9). In fact, the poor agricultural performance in the 1970 s and through the 1980 s and the 1990 s would mean that the sector never really recovered from its decline during the Nigerian civil war of the second half of the 1960 s.

While output of food declined, imports grew. The annual rate of growth of imports stood at about 14.8 per cent during the 1970 s. The imported food products were no longer just the so-called luxuries, but included even the basic food items such as yam, maize, rice, wheat and fats, all of which were formerly produced locally and in sufficient quantity for the local population. During the 
period 1970-1980, the import of food items such as rice and maize grew at an estimated average annual rate of about 50 per cent, with the growth rate in the second half of that decade having mostly accounted for the high estimate (FAO Trade Yearbooks, various issues). A continuous food import, though, could not be sustained by the country's dwindling foreign exchange reserves. As oil (petroleum) revenue declined appreciably, so arguments for self-sufficiency and import bans gained upper hand. A ban on the imports of maize and rice was declared late in 1985 followed by more bans on the imports of wheat, stockfish, vegetable oils and day-old chicks (Forest, 1993: 186).

It became apparent that Nigeria had descended into a food crisis, as both imports and the locally produced food decreased. The causes of the shortages were officially claimed to be drought related, among others.

This paper examines the root causes of the ongoing food crises in Nigeria. First, we look at the country's food production in terms of its characteristics and the categories of producers. We argue that food production by all categories is best classified as inefficient and that the country's food sector, in general, is a low productivity one. We argue further that with the continuously increasing population, and the decreasing output of food (a combination which reflects a fall in per capita food production), a more suitable policy should have to be developed to reverse the food output trend. We proceed to discuss policy interventions in agriculture, looking into issues such as why governments in some developing countries intervene in agricultural production. We also introduce a theoretical model of the impact of policy mechanisms on agricultural output. We also look at the issue of the target group of the policy mechanisms. We proceed to discuss the steps taken so far by the Nigerian authorities to solve food shortages in the country. Finally, we make a few recommendations in our concluding remarks.

\section{FOOD PRODUCTION IN NIGERIA}

\subsection{Main characteristics}

Food production in Nigeria is a predominantly peasant affair, the participation by government and some members of the urban elite in recent years notwithstanding. Output development as from the 1970s onward has shown that agriculture in the country has not outgrown the type that is characterised as inefficient and of a low productivity that can barely sustain the farm population, let alone the burgeoning urban population. Farming method is old fashioned and primitive. The main farming tools are hoes and cutlasses and, to a lesser degree, animals such as donkeys. The use of donkeys is most common in the northem 
part of the country where they assist in the tedious task of ploughing and tilling the soil. Land is more or less fixed, labour being the only variable input. Production is labour intensive. The use of machines such as tractors is rare for the main reason that the predominantly peasant farmers lack the resources to acquire them. The few non-peasant farmers who do use machines lack the knowledge for proper utilization of such capital machinery. These comprise rich businessmen, retired army officers and government officials, most of whom have taken up farming merely as a hobby or simply as a way of enhancing their position in the society. Often, these farmers do not use the machines on large tracts of land and, as a result, such capital equipment is grossly underutilized. The use of fertilizers is also low compared to other countries with relatively developed agriculture. Table 1 below compares Nigeria to selected countries with respect to their use of agricultural inputs and their attained productivity levels. Nigeria clearly stands out as the country that applies the least modern farming techniques in the form of machinery and fertilizer usage. Its low level of agricultural productivity (also shown in Table 1) reflects the country's poor farming techniques and actually provides some insight into the economics of subsistence agriculture. Farming characteristics in Nigeria, in general, provide an economic rationale for the generally observed low agricultural productivity in most developing countries similar to Nigeria where the sector is usually dominated by several fragmented small family farms (Todaro, 1994: 305).

\section{Table 1 Agricultural inputs and labour productivities in selected countries}

\begin{tabular}{|l|c|c|c|}
\hline Country & $\begin{array}{c}\text { Fertilizer } \\
\text { consumption } \\
\text { (Hundreds of } \\
\text { grams per hectare } \\
\text { of arable land) } \\
1995-1997\end{array}$ & $\begin{array}{c}\text { Agricultural } \\
\text { machinery } \\
\text { (Tractors per 1000 } \\
\text { agricultural } \\
\text { workers) 1994- } \\
1996\end{array}$ & $\begin{array}{c}\text { Agricultural } \\
\text { productivity } \\
\text { (Agricultural } \\
\text { value-2dded per } \\
\text { worker) 1995- } \\
1997\end{array}$ \\
\hline Argentina & 254 & 190 & 13833 \\
\hline Japan & 4168 & 593 & 28665 \\
\hline Malaysia & 6375 & 23 & 6267 \\
\hline Nigeria & 68 & 1 & 541 \\
\hline USA & 1134 & 1452 & 34727 \\
\hline
\end{tabular}

Notes:

(1) Fertilizer consumption measures the quantity of plant nutrients used per unit of arable land. Fertilizer products cover nitrogenous potash and phosphate fertilizers.

(2) Agricultural machinery refers to wheel and crawler tractors (excluding garden tractors) in use in agriculture at the end of the calender year specified or during the first quarter of the following year. 
(3) Agricultural productivity refers to the ratio of agricultural value-added, measured in constant 1995 US dollars, to the number of workers in agriculture.

Source: The World Bank (1999, World Development Indicators 28-32, 124-31.

\subsection{Categories of producers}

Producers of food in Nigeria can be grouped under four categories. Family members working in family-owned farms come under the first category. In the christian/pagan south, farm labour under this first category comprises male and female family members, but predominantly male family members in the muslim north. Under the second category are part-time farmers who also work as hired labourers comprising mainly young men and, to a lesser degree, women. These farmers sell their services during peak seasons of ploughing the fields and harvesting the crops, when production requires far more labour than the average farmer-family could supply. Food producers under the third category are the socalled self-proclaimed farmers comprising of urban businessmen, retired military officers and government officials. Producers under this category claim to practise mechanized farming despite their lack of training for the task. These producers have access to credit and do actually acquire the necessary machines and other sophisticated equipment for mechanized farming.

Government-recruited farmers come under the fourth category of food producers in Nigeria. These farmers receive wages to produce food in government-managed farms such as the farm settlements and plantations that are scattered all over the country. Usually, the government farms receive priority over other farms during the allocation of the agricultural share of federal budgets. All categories of farmers in Nigeria have a common feature: their progress and sustainability are marred by low productivity. Table 2 below shows the situation of agricultural labour force and output for selected years, 1960-1998. The table reveals that in spite of the fact that the agricultural sector accounts for most of the employment in Nigeria, at least, until 1985, it accounts for a much lower share of the output long before 1985. Such a trend reflects a relatively low level of agricultural labour productivity, which is common among many less developed countries (Todaro, 1994: 283-4). The table also reveals a sudden increase in the sector's labour force in 1985. A severe drought in the country in 1983 and the subsequent food shortage as the afternath forced many people back to the farms. Government-financed irrigation facilities were also rejuvenated during the period. As is revealed in the table, agricultural share of output during the period still reflected a low labour productivity though, despite the sudden attention to the sector. 
Studies have also revealed that in terms of land productivity, measured as tons of grain harvested per hectare of agricultural land, the Nigerian situation is dismal compared to those of countries like Japan and the USA, both of which practise mechanized farming. Back in 1985, when Nigeria was supposed to be reaping the gains from its several rejuvenated irrigation facilities and other agricultural development projects, the Japanese and USA land productivities were about 725 per cent and 600 per cent, respectively, that of Nigerian land productivity (ibid: 289 ). The situation has remained dismal in Nigeria even in recent years. During the period 1995-1997, the land productivity, measured as kilograms of grain per hectare, was 1191 compared to 1269 during an earlier period 1989-1991. That was clearly a decrease of 6.1 per cent in the later period (World Bank, 1999: 129).

Table 2 Output and employment in Nigerian agriculture, 1960-1998

\begin{tabular}{|c|c|c|}
\hline Year & $\begin{array}{c}\text { Percentage of labour } \\
\text { force in agriculture }\end{array}$ & $\begin{array}{c}\text { Output of agriculture } \\
\text { as percentage of GDP }\end{array}$ \\
\hline 1960 & 80.1 & 65.1 \\
\hline 1965 & 78.1 & 50.0 \\
\hline 1970 & 75.2 & 41.0 \\
\hline 1975 & 64.2 & 40.3 \\
\hline 1980 & 60.2 & 29.9 \\
\hline 1985 & 68.6 & 32.9 \\
\hline 1990 & 43.0 & 36.0 \\
\hline 1995 & 48.5 & 28.0 \\
\hline 1998 & 47.3 & 31.7 \\
\hline
\end{tabular}

Source: UNDP, Human Development Report (various issues); The World Bank, 1999, World Development Indicators: 28-31; Federal Office of Statistics (FOS), National Accounts of Nigeria (various issues); Oyejide, 1986: 37

Nigeria has a vast amount of cultivable land estimated to about 72 million hectares, out of which about 34 million hectares were cultivated in the early 1980s (Oyejide, 1986: 15, Ilorah, 2000b). Of the 34 million hectares cultivated, about 6.5 million hectares were devoted to grain production. About a decade and half later in 1995/97, the amount of land devoted to grain production has increased to about 18.1 million hectares (World Bank, 1999: 125). Despite this increase in land, the output of grain fell by about 6 per cent, and therefore exacerbated the food crises in the midst of a growing population. The poor output level reflects the retrogressive nature of the land under cultivation as a result of poor maintenance and under-utilization of production factors. 
Farmers in the category of family-owned farms lack not only capital but also the necessary expertise required for modern agriculture. These farmers also lack other support services such as good roads and reliable transport services for easy access to the farms as well as to the marketing centres where their products are sold. Their common mode of transport, at best, are bicycles and, in some areas, donkeys. At worst, they walk to the market centres carrying with them heavy loads of farm products. The whole exercise of bearing heavy loads and walking to the marketing centres affects the farmers' health, particularly since the trips are often long (up to twenty kilometres in certain areas) and tiresome. Farmers' total work time (excluding leisure time) is therefore divided between actual working time (time spent working in the farms as well as selling farm products), and the time wasted because of sickness. Poor health consumes time that should otherwise be spent working in the farms. Wasted work time impacts negatively on labour productivity (Linder in King, 1980). Physical health, it is argued, most clearly reveals the close linkage that exists between low levels of income and low levels of productivity in developing countries, since a worker's poor health can adversely influence his or her attitude toward the job and the people at work (Todaro, 1994: 47). A worker has to be both physically and emotionally active in order to withstand the daily pressures of competitive work, or low productivity sets in.

Farmers in the hired-labour category lack motivation and the joy in farming. They only engage in farming, albeit part-time, because of lack of alternative employments. Underutilization of labour manifests visibly among farmers in this category. Many of these farmers work much less than they should do. Their participation in farm work is seasonal. They lack of alternative non-farm employment during off-peak seasons. Yet, as late as 1978, of the total farmers in Nigeria, only slightly above 50 per cent worked as full-time farmers. The rest worked either as part-time farmers or as farm labourers (FOS, 1979: 11). These farmers' lack of motivation in subsistence farming became apparent during the oil boom years of the 1970 s in Nigeria, when they very quickly abandoned agriculture in search of urban jobs. When the boom phased out, many of them were reluctant to return to farming partly because of self-pride aggravated by their loathing for the farming profession, and also because many of them had been absorbed into the country's expansive urban informal sector (comprising activities such as petty trading, carpentry, motor mechanics, bicycle repairs, etc). The Nigerian urban informal sector is generally characterized by low productivity. Reduction in hours put into several informal sector work by this group would most probably have a negligible impact on total output, since a great majority of them idle around city centres in disorganized fashion searching for potential customers. They could go for days and weeks without work, which is why occasionally, some of them rush back to the farms during peak seasons to sell their services for quick money. Generally, food producers under the 
hired-labour category choose an in-and-out pattern of farming rather than sticking to the profession as steady work. Their attitude results from the fact that subsistence farming is unattractive because of low standards of living that manifest in the form of poor health, low incomes and general poverty. Other undesirable factors such as lack of credit facilities and the necessary support services also add to the disincentives. These farmers therefore would rather stay away from agriculture in favour of other activities including leisure; they are wary of being "trapped" like the full-time producers, many of whom are considered to have constant health problems.

The self-proclaimed farmers in the urban elite category are neither trained as farmers nor is farming, in the real sense, a genuine passion to them. It is not a secret in Nigeria that members in this group are proud of being called farmers, but they dislike farming. Branded as "overnight" farmers by Collier (1983: 212), these producers use farming as a camouflage to wash clean their ill-gotten money acquired through corruption and financial malpractices. In some sense, farming accords members in this group an illusive status in the society for "condescending" to food production that is a supposedly a peasant affair. Most important of all is the access to land ownership which farming guarantees them in their claim to produce not only food crops but primary export crops as well (llorah, 2000a). According to the Nigerian land tenure system, a local government has the power to grant customary rights of occupancy to any person or organization who intends to use the land for agriculture, residential and other purposes such as grazing (Fabiyi, 1979). Even with the easy access to facilities for modern farming enjoyed by the elite farmers, it is not uncommon to find that small farmers, particularly those in the group of family-owned farms who have little or no access to facilities, are relatively more efficient producers of most agricultural commodities in the country in terms of total factor productivity. The small farmers produce relatively more output quantity per hectare of cultivated land and at relatively lower costs. A normal situation according to Todaro (1994: 293), would be that large farms are lower cost producers than small farms since the large farms can take advantage of economies of scale, being exposed to farm tractors and combine harvesters as well as large tracts of land.

In Nigeria, the poor performance of farms run by the elite farmers reflects the poor utilization of productive farm resources. It also validates a popular belief that elite farmers value their modern agricultural facilities and the associated privileges not for their potential contributions to national agricultural output but rather for the considerable power and prestige that they bring. Any significant contribution to food output made by this category of farmers is yet to be seen, despite their relatively easy access to land and credit facilities both from government sources and from private banks. Compared to the small farmers, many of who lack access to credit facilities, because of lack of collateral 
securities (llorah, 2000a), the elite farmers have enjoyed credit facilities at very low interest rates. For example, it was not uncommon that they obtained credits at rates of usually not more than 5 per cent (Collier, 1983: 212), which by Nigerian standards is considered very low.

The government-recruited farmers in the final category of farmers work in government-directed food farms and livestock units. These farmers receive wages above their marginal labour productivities, due to government subsidies. Their overrated wages constitute high labour costs (a deterrent to factor productivity), not just to their employers, the government, but most detrimentally to peasant farmer-families who have to compete for hired labour during peak seasons.

In view of the poor productivity of all categories of food producers in Nigeria, coupled with the country's population, that grows above the natural rate, recording an average annual growth rate of 3 per cent during the period 19801997 (World Bank, 1999; 43), the authorities should have embarked on a more viable agricultural policy to combat food shortages, particularly in the long- run. For example, they should have revived the agricultural potentials in the country by not only seriously looking into the plight of the country's devoted farmers in terms of their needs, but also by implementing adopted policies to satisfy the needs, such as: making credit facilities accessible, providing rural infrastructure (roads, transport system, water and health care services), providing safety and security in the farming communities, etc. They should also have stopped government's direct involvement in production since such involvement has mainly driven up production costs through inflated wages.

Most of these policies were adopted but were never implemented successfully. Poor implementation of viable policies meant that the authorities rather resorted to short-run solutions for the food crises. They encouraged imports to fill the output gap between the burgeoning demand for food and the insufficient domestic supply. It turned out that imports became more of a long-run solution. The value of food imports peaked in 1983 when it accounted for about 20 per cent of total import value (Forest, 1993: 187). Even though a severe drought was recorded in the country in 1983, the share of food imports for that year was a staggering one compared to an estimated figure of about 8 per cent in the post civil war year, 1970, that also witnessed an increase in food import. Among the increased imported food items that accounted for the increased expenditure on total food imports, were rice and maize both of which were formerly produced locally and in sufficient quantities for domestic consumption. For example, about 347000 metric tons of maize and 543000 metric tons of rice were imported in 1982 and 1983, respectively, compared to their import figures of 2000 metric tons for rice and 9000 metric tons for maize in 1970 (ibid.). 
Several other factors, apart from poor productivity, lack of proper implementation of policy and explosive population growth, contributed to food shortages and subsequently to the increase in food imports. First, at the end of the Nigerian civil war in 1970, a great number of youths from the rural farming sector, particularly those that had served in the military, abandoned farming. Many of these youths who could not secure alternative non-farm jobs resorted to crimes, harassing and stealing from those who went back to farming, as well as from those that had continued farming even during the war. Such criminal acts against farmers resulted in increased risk in farming, increased production cost, and in decreased incentives and output. Second, having emerged from the civil war, the country, particularly the war tom eastern region (Biafra), received generous quantities of foreign brands of food stuffs. For example, there were foreign brands of wheat, wheaten flour, non-fat milk, rice, frozen fish and meat, etc. These were donated by international bodies such as Caritas international, Red cross, and other international aid agencies. These food stuffs were meant to rehabilitate victims in the civil war affected areas. Later imports of the same food items followed the ones donated by the international bodies. It became apparent that many Nigerians had changed their tastes from the local staples to foreign ones. For example, imported rice, such as Uncle Ben's brands, was preferred to the locally produced ones.

To make things worse for local food producers, the imported food items sold at relatively low prices compared to the locally produced ones. Considering the high labour costs faced by local food producers, it was difficult for their products to compete with the imported food stuffs in terms of profitability. Low food prices that were promoted by imported food also meant that the domestic price ratio between food and manufactured goods turned against farmers as prices of the manufactured goods were not equally low. Incentives for serious farm work were therefore eroded for many farmers, and that encouraged further increases in food imports. Apparently, the price of imported food did not remain low in the long run, particularly when the burden on foreign exchange reserves became overwhelming, placing strain on the balance of payments, and the country sunk deeper in debt crises. A third factor that contributed to food shortage were the droughts of 1973-1974 and a more severe one later in 1983. The drought incidents were the official version of the authorities to explain the food shortage and justify increased imports. With that kind of explanation, the government also attempted to justify expenditures on several of its projects, the majority of which have failed because of the involvement of and intrusions by its inefficient managers. An example was the expenditure on government irrigation projects, which were prioritized over all other agricultural-related expenditures, receiving over $\mathbf{4 7}$ per cent of federal expenditure on agriculture, under the revised third national development plan 1975-1980 (Forest, 1980). The government irrigation projects are yet to bear fruits. The fact that drought- 
related incidence dictates, to a large extent, the performance of the country's agriculture demonstrates the overly precarious nature of that sector. Fourth, the period 1973-1982/83 coincided with the oil boom when the international price of petroleum and related products soared to unprecedented levels. Nigeria, being an oil producer, and therefore enjoying increases in international demand for its oil, experienced a tremendous influx of foreign exchange into the country. The local currency, naira, appreciated and encouraged more food imports. The naira recorded an appreciation of about 17 per cent during the period 1973-1980 (Oyejide, 1986: 27; Ilorah, 1999). The effect of exchange rate appreciation on the volume of food import was mostly felt during the period 1978-1982/3, when the import volume recorded an average growth rate of over 100 per cent compared to its level a decade earlier (FAO Trade Yearbooks, various issues). A more serious effect of the exchange rate appreciation was the decline in output and employment in the country's exports (particularly primary crops) and import-competing (food and manufacturing) sectors. The authorities resisted any devaluation of the local currency, naira, (IBRD, 1986:72), their main argument being that the naira exchange rate should adequately reflect the country's balance of payment position (Oyejide, 1986: 27; Ilorah, 1999). The fact was that the authorities had embarked on several excessively ambitious industrialisation programs, encouraged by the oil boom-related capital inflow and the overvalued naira, and had overlooked the consequences on the agricultural sector. Apparently, the overvalued naira led to economic curruption, gross misallocation of resources, and widespread inefficiencies. A fifth factor that contributed to food shortage was the fact that the oil boom also gave rise to a general increase in the level of economic activity in the country, particularly in the services sector. Formal sector wages, including those paid to workers in the government-managed farms, were adjusted upward. The most significant upward adjustment of wages during the oil boom-dominated years was the Udoji Award in 1975/76, which granted workers wage increases of between 30 per cent and 131 per cent (IMF, 1975: 319; llorah, 1999). The response from the peasantry was to flee the rural sector and farming and head for the cities in search of better paid jobs. To meet the food demand of the increasing urban population, food imports were encouraged.

The policy of encouraging food imports was sustained as long as the oil boom (the influx of foreign exchange) lasted. By the mid-1980s, a decline in the exchange earnings of the oil sector was beginning to be felt. The strong local currency, the naira, was also beginning to weaken against the US dollar and other major currencies, following successive exchange devaluations that intensified during the middle 1980 s and afterwards, after much pressure on the Nigerian authorities. The decrease in foreign exchange earnings coupled with the weakening naira meant that a change in policy over food imports (and imports in general) was inevitable. The authorities turned to a more protective 
stance towards domestic food production. Several reforms were introduced in the context of a structural adjustment program aimed at promoting market forces and private enterprise. For example, the federal and state governments were to completely withdraw their involvement in agricultural production. In practice though, they continued with their involvement indirectly through their officials who form part of the elite farmers. Privatization of agricultural parastatals was launched, and agricultural input subsidies reduced. There was also an initiative to improve rural infrastructure through the directorate of foods, roads and rural infrastructure. These efforts were merely initiatives that were never followed through and therefore never yielded positive results. No wonder the quantity of food output in the country has continued to fall short of local demand.

\section{GOVERNMENT POLICY INTERVENTIONS IN AGRICULTURE}

\subsection{Reasons for government intervention}

Governments intervene in the affairs of their domestic agriculture for reasons that may vary from country to country. In some countries, government intervention is aimed at increasing and boosting the standard of living of the agricultural population. Such intervention is not limited to developing countries, but occurs even in developed countries (OECD, 1961). It is assumed that farm incomes fail to keep up with rising income in the non-agricultural sectors. The low levels of farm incomes, particularly in developing countries, manifest quantitatively and qualitatively in the form of inadequate housing, poor health, limited or no education, high infant mortality, low life and work expectancy, and a general sense of hopelessness (Todaro, 1994: 38).

It is also generally believed that agriculture is considered the financial responsibility of most less developed countries' governments and, hence, the intervention by those governments. Such intervention is most visible in the marketing of export crops by government authorities who, by law, set the prices received by farmers, rather than let market forces of demand and supply determine producer prices (Ilorah, 2000b). Governments also intervene in an attempt to increase the degree of agricultural self-sufficiency, either replacing imports or adding to exports (Ritson, 1978: 352).

Whether governments intervention in agriculture is aimed at income support for farmers, raising funds for the governments, or promoting self-sufficiency, the results of interventions should be seen as the ultimate criteria upon which the policy measures should be judged. Unfortunately, most devices used by governments to raise farm incomes or to attain the other goals are, in fact, not 
capable of meeting those objectives. Not only are most of the policies unsuitable, but there is a chronic lack of devices for implementation even when the policies are suitable. Policy devices are unlikely to fulfill the commonest subsidiary goals if there is no improvement in productivity and income distribution.

\subsection{The impact of policy mechanisms - a theoretical model}

We introduce a partial equilibrium model of agricultural trade based on Ritson (1978). The model analyzes the impact of a policy mechanism that seeks to raise farm output in the form of increased domestic supply. It is assumed that an increase in output will increase farm revenue that will in turn boost incentives for more production. The model has some important limitations. It is concerned with the impact of government policies on the domestic market. It does not show the corresponding adjustments in the world market. It is also strictly limited to the case where the country's exports or imports are insignificant in world terms, having no perceptible influence upon the world price of the product or products.

We assume an open economy where the government regulates neither exports nor imports. We consider the product at a farm-gate stage in the production process. We therefore derive the demand curve from final consumer demand through the marketing process. See Figure 1 as illustration.

Figure 1 The impact of policy mechanism on farm output

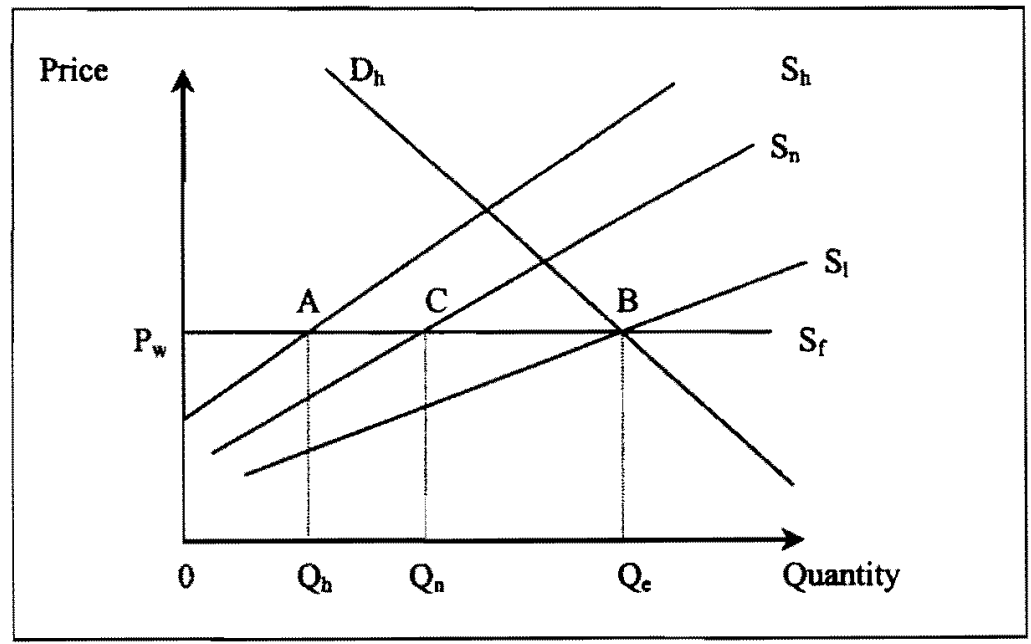


The world price $P_{w}$ at the port of entry is directly competitive with the farm gate price of supplies from domestic sources. The horizontal line $S_{f}$ represents an infinitely elastic free-trade foreign supply curve of the food commodity. $S_{b}$ and $D_{h}$ are domestic supply and demand curves, respectively. $O Q_{h}$ of food is produced domestically, while $\mathrm{Q}_{\mathrm{b}} \mathrm{Q}_{\mathrm{e}}$ is imported. Domestic producers receive the amount $O \mathrm{p}_{\mathrm{w}} \mathrm{AQ} \mathrm{Q}_{\mathrm{b}}$ as revenue from the sale of their food product. The amount spent on imports, in terms of domestic currency, is $\mathrm{Q}_{\mathrm{b}} A \mathrm{BQ}_{\mathrm{e}}$. A good policy could shift the supply curve rightward to $S_{n}$ resulting in the following: a positive production effect, implying an expansion of domestic production from $\mathrm{OQ}_{\mathrm{b}}$ to $\mathrm{OQ}_{\mathrm{n}}$; a positive revenue effect, implying an increase in domestic producers' aggregate revenue from $O \mathrm{P}_{w} \mathrm{AQ}_{\mathrm{h}}$ to $\mathrm{OP}_{\mathrm{w}} \mathrm{CQ}_{\mathrm{n}}$; a positive trade effect, implying a decline in resources spent on imports from $A B Q_{e} Q_{b}$ to $C B Q_{e} Q_{n}$; and a positive consumption effect, implying an increase in consumption of domestically produced food. The decline in import $\mathrm{Q}_{\mathrm{h}} \mathrm{Q}_{\mathrm{m}}$ is replaced by locally produced food product, and should be considered a positive effect, particularly if the locally produced food is of a better quality than the imported ones. In fact, we should expect a positive consumption effect as long as the locally produced food stuff fulfils the condition of a normal good.

A steady increase in aggregate revenue of domestic producers will boost producer incentives and therefore promote a steady increase in local food production. With time, the country will attain self-sufficiency. The policy will be regarded as nationally worthwhile if, in the short-run, a valuation of the extra output, in the first instance $Q_{h} Q_{n}$, exceeds a valuation of the extra resources spent on agriculture to shift the supply curve rightward. With a continuous improvement in production and an ultimate attainment of economies of scale, promoted by a sustainable good agricultural policy, the supply curve will continue its rightward shift to $S_{l}$, intersecting with domestic demand curve $D_{h}$ at point $B$. At this stage the country attains self-sufficiency. The policy will be regarded worthwhile if a valuation of the entire output that replaces imports exceeds a valuation of the entire resources spent in order to attain a final equilibrium at point $B$.

Policies most likely to shift the supply curve in Figure 1 rightwards are those directed towards improving agricultural productivity. Prioritised areas to improve productivity should include the following: (a) proper agricultural research institutes that target the improvement of quality and quantity of local staples that thrive excellently in the local climate with respect to the soil texture and weather conditions, (b) promotion of large scale commercial food farms that emphasize the cultivation of specific crops on specific pieces of land. (c) proper land management through good maintenance. (d) promotion of the use of agricultural machinery (tractors, combine harvesters, etc.) and a proper training of potential users. (e) improved roads and motor transport to facilitate trips to 
the farms as well as the market centres. (f) availability of water facilities, particularly in those areas most suitable for food production. (g) extensive campaign to encourage a more nutritious eating culture, particularly among the younger members of the population. (h) availability of credit facilities that are more easily accessible (in terms of location and collateral requirements) to all farmers. (i) subsidies on farm inputs such as improved food seedlings, fertilizers, etc. (j) establishment of food producers' information centres. The information could come from farmers themselves concerning new discoveries in the production process which they may want to share with fellow farmers, or it may come from the authorities concerning new policies aimed at improving production. Farmers are therefore kept well informed about new technologies, new improved seeds, market conditions, threatening diseases and parasites and methods of avoiding them, etc. A successful implementation of these policies will serve as an incentive and, with time, high and sustainable productivity will be achieved.

\subsection{The target group of the policy mechanisms}

The main target group of the government support policy is more likely to comprise the few more prosperous farmers that are not very risk-averse. These farmers could easily respond to new farming techniques that are usually most favourable for large scale production. The primary goal of agricultural support policy is to raise farm incomes. From our theoretical analysis, farm income is a product of agricultural output and price. At constant output (product) prices, and with input prices that may be rising, partly as a result of the expenditure on research, and also as a result of expenditure on several other areas of infrastructure, small farmers, who actually make up the majority of total farmers, may not benefit from the project. Not only do small farmers lack the willpower and the financial resources to respond to high risk new technological packages, but the new packages may result in serious income problems for the farmers, particularly if farm costs are forced up by the increase in output by large farms that enjoy economies of scale. Large farms that enjoy economies of scale, can more comfortably replenish their production factors even at increasing factor prices. Channelling public funds directly to small farmers as a form of income support may not prove a better option in view of the fact that such a direct form of support may allow them to enjoy only a tolerable existence rather than being fully exposed to market forces. In other words, a direct form of income support may give false expectations concerning the long-run viability of small farms. Survival of small farms may therefore not be guaranteed by reliance on measures that improve productivity. 
The earliest significant food promotion program by the authorities in Nigeria was the so-called National Accelerated Food Production Program (NAFPP) in the late 1960 s and the early 1970 s. The program was encouraged by the World Bank as part of its drive to promote integrated rural development in the developing countries (Forest, 1980). The program aimed to raise productivity of farmers by introducing to them new technology and intensive project management. The introduced technology was in the form of fertilizers, insecticides, seeds, sprayers and tractor units, all of which were to be administered through the network of farm service centres. The farm service centres, which were under the control of several government ministries, were also to administer the necessary credit, marketing and extension services. The NAFPP failed because it later tumed out that very stringent conditions were required for obtaining the credits, and those conditions were very difficult, if not impossible, for most poor farmers to satisfy. The few elite farmers, who could produce the required collateral securities to obtain credit, were said to have employed the credit to secure for themselves large stocks of grains during harvests and thereafter large profits from seasonal price movements (ibid). In other words, the elite farmers paid less attention to using the credit for producing food crops. They rather bought already produced crops immediately after harvests at very low prices from numerous small poor farmers, who must sell to meet taxes, debt repayments, and expenditure on non-agricultural consumption goods. Later, during off-harvesting seasons (for example, planting seasons) when market supply of crops was generally scarce, they released their accumulated stocks and made huge profits.

The NAFPP therefore failed mainly because the small farmers who were primarily responsible for production could not obtain credit, while the few elite farmers, who did obtain credit, used it for speculative purposes rather than for production. The official version claimed that the program failed because it lacked practical incentives to motivate farmers. Government-owned food farms and livestock units also performed very poorly, even though they had equal access to credit. Most of them ended up sustaining heavy financial losses. A typical example of such government-owned farms were the Cross River State Model Farms, which were started in 1972. By 1977, the farms had acquired about 12198 acres of land and developed about 3167 acres. Later, it was reported that because of excessive central control from the cabinet office, coupled with the inefficiency of undisciplined managers, the farms ran up a loss of over $N 850000$ in just a three quarter period in 1977 (ibid).

The next food promotion program pursued by the authorities was Operation Feed the Nation (OFN). The OFN was launched already in 1976 when the 
failure of NAFPP had become obvious. Officially, the OFN was to promote self-sufficiency in food production through labour mobilization and the supply of subsidized inputs such as fertilizers, seeds and pesticides. Students were encouraged to start their first off-school jobs in government-owned farms. Critics of the project condemned it as a publicity investment for the military government in power. They argued that the authorities mainly sought support from urban groups and students. The result was that while productivity was low, wages were high. According to Sano (1983), the OFN failed not as a public relation enterprise but rather as a development strategy. Apparently, the OFN was a government and students affair as far as peasant farmers were concerned. Even the authorities later acknowledged in their official report (The Green Revolution, 1982: 8) that among the main causes of the failure of the program was that it was not geared to meeting the needs of small farmers.

With the failure of the OFN, the authorities introduced yet another food promotion program called the Green Revolution. The Green Revolution aimed to achieve self sufficiency for the Nigerian population by 1985 . To that end, the agricultural share of government allocated resources was increased tremendously. Sadly though, investments in government owned and managed projects (irrigation facilities, agricultural banks, food farms, roots and grain producing establishments, etc.) continued to be prioritized in government agricultural budget allocations. In other words, the government continued with its full involvement in production, implying that despite the disastrous results of their previous involvements, the responsible authorities refused to leam from their mistakes. Funds provided for the Green Revolution were later, when the program had failed, officially conceded to have been appropriated, in excess of their absorptive capacity, to wealthy businessmen who pretended to be practising large-scale mechanized farming.

The Green Revolution therefore failed because apart from being heavily politicized, and thus largely mired in political conflict, the resources were mischannelled. As soon as it became obvious that the Green Revolution has failed, the government introduced a number of reforms in 1986 under the context of a structural adjustment program (SAP), with its emphasis on market forces and private enterprise. Loans were granted by the World Bank under stringent conditions which (in agreement with Nigerian authorities) included that: federal and state governments withdrew completely from agricultural production; agricultural parastatals be privatized; subsidies on inputs be stopped; fertilizer procurement and marketing be commercialized; rural infrastructure be improved; Agricultural Development Projects (ADPs) be promoted and given priority over exististing wasteful giant and difficult-tomanage projects such as the so-called River Basin Development Authorities and large-scale irrigation projects. Did the SAP improve the production of food in 
the country? The answer to that question requires a closer look at an important arm of SAP, namely the ADPs, and at the contributions they had made.

Originated in the mid-1970s, the ADPs were started as pilot projects to promote food production to a commercial level in the agricultural potentially rich parts of Northern Nigeria such as Gombe, Gusau and Funtua. The period coincided with the oil boom in the country. The local currency was relatively strong and the country could conveniently afford surplus food imports. Nigerians well nourished at the time, albeit from imported food stuffs. A serious implication of running projects during the boom years in Nigeria was that even weak projects were misinterpreted to be high performers simply because the oil-inspired booming economy with its spill-over effects protected most local establishments. Poor performances by several projects went unnoticed. The ADPs were no exception and were disguised as a success story, at least for as long as the boom lasted. The misleading interpretation of the actual situation led to some financial support from the World Bank that even encouraged the activities of the ADPs to be extended country-wide. Their activities included input deliveries (particularly fertilizers at heavily subsidized rates), partnerships with chemical producing companies, development of improved breeds of seeds that could lead to large scale harvests, and provision of infrastructure and extension services. As soon as the oil boom and its associated spill-over effects had phased out, poor performances by the ADPs became more obvious, considering that the food crises resurged in the economy. A follow-up on the ADPs in the 1980s was based on strong tendencies for self-perpetuation, since the projects had created strong administrative, intellectual and material vested interests. There was no doubt among observers that the ADPs failed. According to Forest (1993: 189), the reports on the Gombe and Funtua projects showed disappointing results. At best, the total grain in crop production, for example, in Gombe area, was only 35 per cent of what was anticipated. At the worst, there was no net increase in production generally.

The failure of the projects was attributed to the fact that they neglected some of the core crops in the agricultural regions. The projects encouraged sole cropping even in the areas that have traditionally practised mixed cropping. In the process, production of crops such as maize and sorghum was promoted in Gombe and Funtua areas, respectively, while an important crop such as millet was neglected. Unfortunately, even the promoted ones, particulaly sorghum, proved a total failure. Critics of the projects concluded that their failure was due to the fact that farmers favoured mixed-cropping over sole-cropping that was promoted by the projects (Forest, 1993: 189). The few beneficiaries of the ADPs were the so-called elite farmers that were recruited from urban businessmen, retired military officers and state officials, all of whom had access 
to state and federal government credit. The losers were small farmers and the country's consumers in general.

\section{CONCLUDING REMARKS}

Considering the number of programs that have been introduced by the Nigerian authorities to solve the country's food crises and the subsequent failures of each and every one of them, a radical departure from the old measures becomes necessary. The present mode of farming in the country makes the sector a very risky one. Output performance is dependent on uncertainties such as the highly variable rainfall and a generally demotivated labour. In order to utilize its surplus cultivable land at full capacity, attain self-sufficiency as well as export quantity, the presently practised subsistence farming has to be replaced with a modern commercial farming. Past government programmes to revive food production have failed mainly because of faulty implementation instruments. Obviously, the choice is not between support for several small farmers who not only lack modern farming facilities but have consistently refused to abandon the old subsistence method, and support for few relatively large farms that are managed by few elites who are non-farmers by training. Any support to either of the two is bound to lead to inefficient resource allocation, as was evident in the country. Problems of food production in Nigeria should be solved through a more radical approach that aims at totally restructuring agricultural policy. Specifically, there should be measures directed towards reducing the number of farms and farmers, and increasing farm sizes. Such measures will guarantee an increase in income, since the aggregate income of the sector is distributed among few individuals. Increases in income will promote incentives among farmers to maintain a good standard of output in terms of quality and quantity. As a deterrent against possible unnecessary influx of youths into food production, the authorities should encourage an adequate and broadly based educational system. This is to be followed by incentives for firms to invest in agricultural regions so as to provide wider job opportunities for young people in the rural areas. The existing farmers with limited or no skills outside agriculture, and who are left outside the general provisions of social security and old age pensions, can continue to live on their farms, providing at least a minimum amount of food for their own needs, and often receiving support from their descendants.

For a smooth transition from subsistence farming to specialized commercial farming, it is inevitable that the two should initially coexist. Nevertheless, as soon as commercial profit becomes the criterion of success and survival, since farms should be encouraged to rely on economies of scale to reduce unit labour costs, subsistence farming disappears and specialized commercial farming takes 
over the full control of food production. In other words, farmers in the subsistence category are ultimately phased out. Left behind will be professionally trained farmers to manage the farms, using modem commercial farming techniques. In the structural process, the government should implement pricing policies that reflect market conditions. The government should also tone down their involvement in direct production of agricultural commodities. This will lessen the risk of comupt farmers, particularly the so-called overnight farmers recruited from urban business people and other members of the elite.

Modern commercial farming requires three important factors, namely, cultivable land, capital and expertise. As we have mentioned earlier in a previous section, cultivable land is in abundant supply in Nigeria. Over the years, though, and following a continuous population growth, the land under cultivation has become severely fragmented. The result is that landholdings per family member has shrunk even from their original low levels. Expansion of agricultural land to new virgin areas should therefore be promoted and farmers be encouraged to take risks. Farmers should be encouraged to abandon, albeit gradually, the traditional technologies and crop patterns that are concentrated on small parcels of land. They should rather move to new technologies that promise higher yields on large land areas. For land under usage to achieve its full output potential, through efficient resource allocation, it is important that economics rather than politics be the driving force behind land tenure in general.

Agriculture as an academic discipline should be strengthened in the country's institutions of higher learning. Awareness of the importance of commercial farming, particularly food production, should be instilled in the minds of youths taking courses in agriculture. After successful completion of their programmes, the emerging farmers should be given financial assistance by banks to enable them to start their own farms. Banks should be user friendly to emerging farmers, applying less stringent conditions when giving loans, branching out to the farming communities, and encouraging aggressive farming and output diversification. With time, discipline and perseverance, a good agricultural policy that is successfully implemented will bear fruit, and the country will not only attain self-sufficiency in food production, but will also have enough export quantity to complement the oil sector as a foreign exchange earner.

\section{REFERENCES}

1 COLLIER, P. (1983) "Oil and Inequality in Rural Nigeria", in Ghai, D. and Radwan, S. (eds.) Agrarian Policies and Rural Poverty in Africa, International Labour Office, Geneva. 
2 FABIYI, Y.L. (1979) "Land Tenure Reform in Nigeria: Implications of the Land Use Decree for Agricultural Development", The Jounal of Agriculture, 1: 235-57.

3 FAO, UN, Trade Yearbooks (various issues).

4 FOS (Federal Office of Statistics), (1979) Nigeria Rural Economic Survey 1978/79 (Consolidated Results of Rural Household Enquiries 1978/1979), Lagos.

5 FOS, National Accounts of Nigeria (various issues).

6 FOREST, T.G. (1980) "Agricultural Policies in Nigeria, 1900-1978", in Heyer, J., Roberts, P. \& Williams, G. (eds.) Rural Development in Tropical Africa. Macmillan, London.

7 FOREST, T. (1993) Politics and Economic Development in Nigeria, Westview Press, Oxford.

8 GREEN REVOLUTION (Insurance Against Hunger) (1982) Federal Department of Information, Lagos.

9 ILORAH, R. (1999) "Petroleum and its Consequences for Prices, Employment and Wages in Nigeria", South African Journal of Economic and Management Sciences, 2(1): 143-56.

10 ILORAH, R. (2000a) "A Classification of Different Phases of Development in the Export Sector of Nigerian Agriculture", South African Journal of Economic and Management Sciences, 3 (2): 245-72.

11 ILORAH, R. (2000b) "Explaining De-agriculturalisation in Nigeria: Theory and Evidence", The South African Journal of Economics, 68 (2): 307-23.

12 IBRD (1986) Trade and Pricing Policies in World Agriculture, (World Development Report, Part II), The John Hopkins Press, Baltimore.

13 IMF Report (1975) Survey of African Economies: Nigeria, 6, Washington D.C.

14 KING, J.E. (1980) Readings in Labour Economics, (Edited readings with commentaries by J.E. King), Oxford University Press.

15 LEWIS, W.A. (1967) Reflections on Nigeria's Economic Growth, Development Centre, OECD, Paris.

16 LINDER, S.B. (1980) "The Increasing Scarcity of Time", in King, J.E. (ed.) Readings in Labour Economics, Oxford University Press.

17 OLAYIDE, S.O., OLATOBUSUN, D. \& ESSANG, S.M. (1982) Nigeria's Foreign Trade and Economic Growth, 1948-1964, Nigerian Institute of Social and Economic Research, University Press, Ibadan.

18 OYEJIDE, T.A. (1986) The Effects of Trade and Exchange Rate Policies on Agriculrure in Nigeria, Research Report 55, International Food Policy Research Institute.

19 OECD (1961) Trends in Agricultural Policies Since 1955, Development Centre, Paris. 
20 RITSON, C. (1978) Agricultural Economics (Principles and Policy), Granada Publishing, London.

21 SANO, H-O. (1983) The Political Economy of Food in Nigeria, 1960 1982, Scandinavian Institute of African Studies, Uppsala.

22 TEAL, F. (1983) "The Supply of Agricultural Output in Nigeria, 19501974", Journal of Development Studies, 19: 191-206.

23 TODARO, M.P. (1994) Economic Development, Longman, New York and London.

24 UNDP, Human Development Report, (various issues).

25 WORLD BANK (1999) World Development Indicators, Washington, D.C. 